\title{
Edutainment-Based Learning Model with Powerpoint Media Enhancing Students' Learning Motivation
}

\section{Lenny Susilawati S. ${ }^{1 *}$, Suyanto ${ }^{2}$, Anik Gufron ${ }^{3}$}

1,2,3 Universitas Negeri Yogyakarta, Yogyakarta, Indonesia

\section{ART ICLE I N F O}

Article history:

Received June 16, 2021

Revised June 18, 2021

Accepted July 20, 2021

Available online August 25, 2021

Kata Kunci:

Minat Belajar, Pembelajaran

Berbasis Edutainment

Keywords:

Learning Motivation,

Edutainment-Based Learning Model

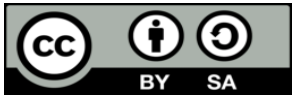

This is an open access article under the CC BY-SA license.

Copyright (C) 2021 by Author. Published by Universitas Pendidikan Ganesha.

\begin{abstract}
A B S T R A K
Rendahnya motivasi belajar siswa terutama pada tingkat dasar dipengaruhi oleh media pembelajaran yang kurang inovatif. Penelitian ini bertujuan untuk meningkatkan minat belajar IPS siswa kelas $V$ melalui model pembelajaran berbasis edutainment dengan powerpoint. Jenis penelitian yang digunakan adalah penelitian tindakan kelas yang dilaksanakan dengan model Kemmis dan Taggart. Obyek penelitian ini adalah proses pembelajaran IPS dan minat belajar IPS siswa kelas V sekolah dasar (SD) dengan menggunakan model pembelajaran berbasis edutainment dengan powerpoint. Teknik pengumpulan data melalui observasi langsung, angket, dan wawancara. Instrumen penelitian ini adalah peneliti dengan alat bantu berupa pedoman wawancara. Penelitian ini dilakukan selama dua kali putaran (siklus) dan dilakukan penyempurnaan strategi pembelajaran dalam setiap siklusnya. Hasil penelitian menunjukkan bahwa pembelajaran IPS menggunakan model pembelajaran berbasis edutainment dengan powerpoint dapat meningkatkan minat belajar IPS siswa kelas V SD. Berdasarkan hasil observasi sebelum dilaksanakan penelitian diperoleh rata-rata persentase sebesar 60,00\% dengan kategori sedang, setelah dilaksanakan penelitian menjadi 76,67\% dengan kategori tinggi pada siklus I, dan 88,33\% dengan kategori tinggi pada siklus II. Berdasarkan hasil angket sebelum penelitian diperoleh persentase sebesar 55,08\% dengan kategori sedang, setelah penelitian meningkat 73,31\% pada siklus I dengan kategori sedang, dan 81,37\% dengan kategori tinggi pada siklus II. Temuan tersebut menyiratkan bahwa penggunaan media pembelajaran yang dikembangkan dapat meningkatkan motivasi belajar siswa sekolah dasar secara signifikan.
\end{abstract}

\section{A B S T R A C T}

The low student learning motivation, especially in the elementary level, is influenced by outdated learning media. This study aims at improving students' learning motivation in social sciences among fifth-grade students through an edutainment-based learning model with PowerPoint. This research employed Classroom Action Research adapting Kemmis and Taggart model. The object of this research was the social sciences in Elementary School. The data collection techniques were through direct observation, questionnaires, and interviews. This research was conducted in two cycles and the improvements were made in the form of learning strategies in each cycle. The results showed that the learning process of social sciences using the developed PowerPoint could improve the students' learning motivation among the fifth-grade students of the elementary school in the social sciences subject. Based on the observation results before the study, the average percentage was $60.00 \%$ or in the moderate category. After the research was carried out, it became $76.67 \%$ for the first cycle, and $88.33 \%$ or in the high category for the second cycle, respectively. The questionnaire results before the study were $55.08 \%$ or in the moderate category. After the learning process with the developed PowerPoint, it increased to $73.31 \%$ in the first and $81.37 \%$ in the high category in the second cycle, respectively. It indicates that the use of the developed learning media can significantly enhance students' learning motivation among the students at elementary school.

\section{INTRODUCTION}

This rapid development of technology must be in line with the up-to-date learning process. A young learner at elementary level should also be introduced with technology in a positive way as early as possible to train them to utilize technology for their self-development (Astini, 2020; Puspitarini \& Hanif, 2019). In fact, outdated learning media seem to be found in many elementary schools that affect low student learning motivation. Learning media can be defined as a tool in the form of a physical and nonphysical used teacher in conveying material to students to be more effective and efficient (Husain, 2014). It urges the world of education to create the tool that can change teaching and learning activities to be more fun and entertaining. Teaching and learning process must equally fostering the variables of interest, attitude and learning habit to achieve a high level of students' achievement (Hashim et al., 2021). Teachers' motivational beliefs play a crucial role for effectively applying technology in learning instruction 
(Backfisch et al., 2020). It can be realized through an edutainment-based learning model, one of which with PowerPoint. Teachers believed that PowerPoint presentations made the content more appealing; therefore, they helped them to take students' attention. Pictures and sounds that appear can raise students learning motivation that stimulates them to explore more on the material content. Learning media that can act as tutors and encyclopedias will provide information and feedback to students quickly where students don't just sit and listen passively, but they must think and give responses. This presentation can be in the form of automatic slides containing material that are interactive using multimedia elements with a mouse or keyboard as a controller for the presentation (Madcoms, 2010). The PowerPoint presentation can be specially designed for educational purposes whose presentation is mixed with entertainment elements of the material that can directly manage the learning process by inviting students to interact with the subjects programmed into the system. By doing so, the positive aspects of using technology will be gained by both students and teachers (Genc Ilter, 2009; Rivai et al., 2003). When students are active in the learning environment, it means their learning interest increases.

PowerPoint enables the users to insert audio/music materials as a mean to improve encode, store, and gain a better understanding which makes memorizing easier and motivate them to learn in an enjoyable situation. Media integrated with technology such as PowerPoint game has also been agreed to be able to bring a new atmosphere of learning, such as more interesting, challenging, and making the students more confident in expressing their opinion in the classroom (Bahrami et al., 2019; Ratminingsih, 2018). It means that using PowerPoint can be a positive way to provide a learning model among young learners with the real context of learning, besides it also provides instant feedback that lets learners know immediately if they have given the wrong answer.

Based on the observations in one of elementary schools in Yogyakarta, Indonesia in the social science learning, the average of students learning motivation for fifth-grade students seems very low where students rarely involve in the learning process. Most students often talked and joked with friends nearby during the teacher explanation and practice session. They were not getting involved during the learning process, as well as when asked by the teacher whether there were difficulties of which none expressed their opinions. None students responded when the teachers' open discussion session. It highly indicates the low learning motivation among the students. As mentioned earlier that the inappropriate or conventional learning media seems to play big role in the low students' involvement. The learning model can attract more students' attention if it is completed with proper learning media. Students learned better if the course material was presented through some visual tools since the method that teachers use in their teaching process is crucial to facilitate learning (Ozaslan \& Maden, 2013; Rivai et al., 2003). This claim is supported by several relevant studies. The development of edutainment-based learning media with PowerPoint for VII grade students at junior high school with Fractional Number Operations could increase the students' motivation in Mathematics learning based on the results of the study that $93.75 \%$ of students became more interested in the learning session (Trisnani, 2020). Even, the use of PowerPoint had a significant positive effect on learners' scores (Lari, 2014). As clarified in the previous studies, PowerPoint plays crucial role to enhance the students learning interest, especially the young learner. As matter of fact, rarely do the teachers create PowerPoint for their learning instruction. By having Classroom Action Research, this study aims at facilitating teachers to enhance students' learning motivation by using an edutainment-based learning model with the developed PowerPoint in social learning among the fifth-grade students of elementary school.

\section{METHOD}

This study employed the spiral action research model developed by Kemmis and Mc. Taggart in (Burn, 1999). Action research is one of the type investigations that has characteristic reflective participative, collaborative, and spiral that have purpose to repair and to increase the system, method, process, substance, competence, and situation (Arikunto, 2016). This classroom action research was conducted in two cycles consisting of several stages in each cycle, namely planning, action, observation, and reflection. To measure the development of students' learning motivation, a questionnaire was distributed to the students. Initial observations were made to find out the right action to improve students' motivation in social sciences subjects. After the initial observation, the researchers were discussing with the teachers to determine the action model to enhance students' learning motivation. The discussion resulted in the application of the edutainment-based learning model with the developed PowerPoint as an effort to enhance students' motivation during the learning process.

The data in this study were gathered from the interactions between teachers and students as well as students and peers during the classroom learning process. The data was collected by direct observation, questionnaires, and interviews. The instruments consisted of (1) the researchers who acted 
as planners, data collectors, analyzers, data interpreters, and reporters of research results based on observation sheets and field notes, (2) the student questionnaire, (3) the interviews, (4) the documentation. The instrument in the form of questionnaire is distributed to a sample of 40 primary students and teachers. The content validity was assessed by the experts and the construct validity was measured by Exploratory Factor Analysis (EFA) (Ghazali, 2016). The reliability of the instrument was measured using internal consistence reliability by alpha coefficient reliability or Cronbach Alpha. The finding of this pilot study showed that the instrument is valid and reliable. This questionnaire was arranged using a Likert scale based on three indicators into 34 items and consisted of positive and negative questions randomly. The alternative responses and scores, i.e.: $S A=$ strongly agree, $\mathrm{A}=$ agree, $\mathrm{D}=$ disagree, $\mathrm{SD}=$ strongly disagree. For positive questions, the answer scores were $\mathrm{SA}=4, \mathrm{~A}=3, \mathrm{D}=2$, and $S D=1$, while for negative questions the answer scores were $S A=1, A=2, D=3$ and $S D=4$. The questionnaire guidelines on positive and negative statements are shown in Table 1.

Table 1. The Questionnaire Guidelines

\begin{tabular}{lccc}
\hline Indicators & $\begin{array}{c}\text { Positive statements } \\
\text { numbers }\end{array}$ & $\begin{array}{c}\text { Negative statements } \\
\text { numbers }\end{array}$ & Number \\
\hline Attention & $1,15,21,23,29$ & $4,10,26$ & 8 \\
Relevance & $2,5,13,20,22,23,28$ & 8,25 & 9 \\
Confidence & $3,6,11,27,30$ & 9,17 & 7 \\
Satisfaction & $7,12,14,16,18,19,32$, & 31 & 10 \\
\hline \multicolumn{1}{c}{ Total } & 33,34 & $\mathbf{8}$ & $\mathbf{3 4}$ \\
\hline
\end{tabular}

The data analysis process was started by examining all available data from various sources (questionnaires, interviews, observations). In this study, the collected quantitative data in the form of observation results, questionnaire results data analysis, interview data analysis, and learning implementation data analysis were processed with statistical formulas. Analysis of the results of observations of interest in social studies learning was carried out quantitatively and descriptively by calculating the scores of each aspect of students' motivation among the fifth grade by calculating the percentage of the score. The calculation of the average students' learning motivation in each cycle was done based on the predetermined categories to make conclusions on the students' learning motivation. To achieve the credibility of the data or to check the validity of the data from the research, the triangulation method was done by matching the results of the observations with data obtained through interviews and documentation. It was also done by asking for considerations and responses from the teachers, colleagues, and the research subjects. Trustworthiness consists of (1) credibility; in preferences to internal validity, (2) transferability; in preference to external validity/generalizability, (3) Dependability; in preference to reliability, (4) confirmability in preference to objectivity (Lincoln, Y.S., Lynham, S.A. \& Guba, 2011). In this research, the researcher uses credibility to establish the trustworthiness.

There are several techniques to increase credibility degree, one of them is triangulation. The aim of triangulation was to increase one understands of whatever being investigated (Flick, et al, 2004). There are four kinds of triangulation, they are: (a) source triangulation, (b) method triangulation, (c) researcher triangulation, and (d) theory triangulation (Creswell, 2014). In this research, researcher used source triangulation. There are four kinds of triangulation. They are data triangulation, investigator triangulation, methodological triangulation, and theoretical triangulation. This research uses two kinds of triangulation. The first was data triangulation by using many sources of data to validate it. The data to be taken from the informant was compared to the data from the other informant. The second was methodological triangulation utilizing many methods to validate data. The data to be taken from interview was compared to the data taken from observation and the questionnaire results. In the other words, the researcher limited of the technique of establishing the trustworthiness on credibility through source and methodological triangulations.

\section{RESULT AND DISCUSSION}

\section{Result}

Based on the results of the observations of in the fifth class of Elementary Schools, it was found that the learning process carried out so far tended to use conventional learning, i.e., only the lecturing method without any media. In general, based on the results of the observations, it appeared that the attention and curiosity of students in participating in the learning process were relatively low. To strengthen and support the obtained data, the questionnaires and interviews were proposed of which the 
researcher used written questions by asking why social studies lessons were not considered fun. The results of student responses are summarized in Table 2.

Table 2. The Students' Responses on why the social subject is not fun

\begin{tabular}{clcc}
\hline No & Response & Frequency & $\mathbf{\%}$ \\
\hline 1 & Boring learning model & 9 & 47 \\
2 & Abundant materials & 7 & 37 \\
3 & Lack of supporting books & 3 & 16 \\
\hline
\end{tabular}

Students' responses about why social studies lessons were not fun can be grouped into three reasons categories. The responses of students who stated that the social studies method was not fun were the biggest (47\%), the second was the abundant material (37\%) and the rest gave opinions that they did not have supporting books (16\%), respectively. It is consistent with the ideas that Young learners in this study were the 5th-grade elementary school students and they are considered as young learners since their age is around 9-10 years. They have some special characteristics to be considered by the teacher if they are learning a subject matter, a quite short attention span, and easy to get bored are the common special characteristics of young learners (Juhana, 2014). Teaching young learners can be done successfully if the teacher uses media with good visual aids, colorful objects, and combined with a game that attracts them (Ratminingsih, 2016). It is time to depart from default PowerPoint and adopt multimedia principles to enhance comprehension and improve short- and long-term knowledge retention and educators may be trained and encouraged to apply multimedia principles for designing and delivering effective lecture (Nagmoti, 2017). After the discussion session with the teachers, the classroom action research was carried out in two cycles where each cycle consisting of two meetings with the material as shown in Table 3.

Table 3. The material content of the PowerPoint

\begin{tabular}{clr}
\hline Cycle & \multicolumn{1}{c}{ Materials } & \multicolumn{1}{c}{ Indicators } \\
\hline I & The business fields in Indonesia & - able to mention the types of businesses in the \\
a. Agriculture & community. \\
b. Trading & - able to provide examples of self-managed and \\
c. Industry & group businesses. \\
d. Service & able to give examples of production, \\
The business entities & $\begin{array}{l}\text { distribution, and consumption activities in } \\
\text { a. Individuals } \\
\text { b. Groups }\end{array}$ & Indonesia. \\
Business activities & appreciate others business or work \\
Know the types of business and working & Make a visit report to one of the producers \\
activities in Indonesia.
\end{tabular}

During the implementation of the action stage, the researcher observed the students' motivation in social subjects. The observations were carried out by observing the students. The observation sheet consisted of three aspects, namely attention, pleasure, and curiosity. The observation results were supported by the results of the questionnaire in which the students learning motivation was getting higher after treated with an edutainment-based learning model with the developed PowerPoint. The level of students' motivation can be found out by using the ARCS model (Attention, Relevance, Confident, and Satisfaction) developed by John Keller (Rahardjanto et al., 2019). The results of the questionnaire percentage of students' learning motivation in the first cycle were $73.31 \%$ or the medium category. In the second cycle, the average increased to $81.37 \%$, or in the high category as presented in Figure 1. In the implementation of learning (action), the teacher used the developed PowerPoint as the learning medium, while the researcher observed the learning process. During the process, the teacher taught the students using the lesson plans that had been prepared. This classroom action research was carried out in two cycles, where each cycle was carried out in two meetings covering planning, implementation of actions, and observations consisting of opening, core activities (meetings I and II), reflection, and closing. 


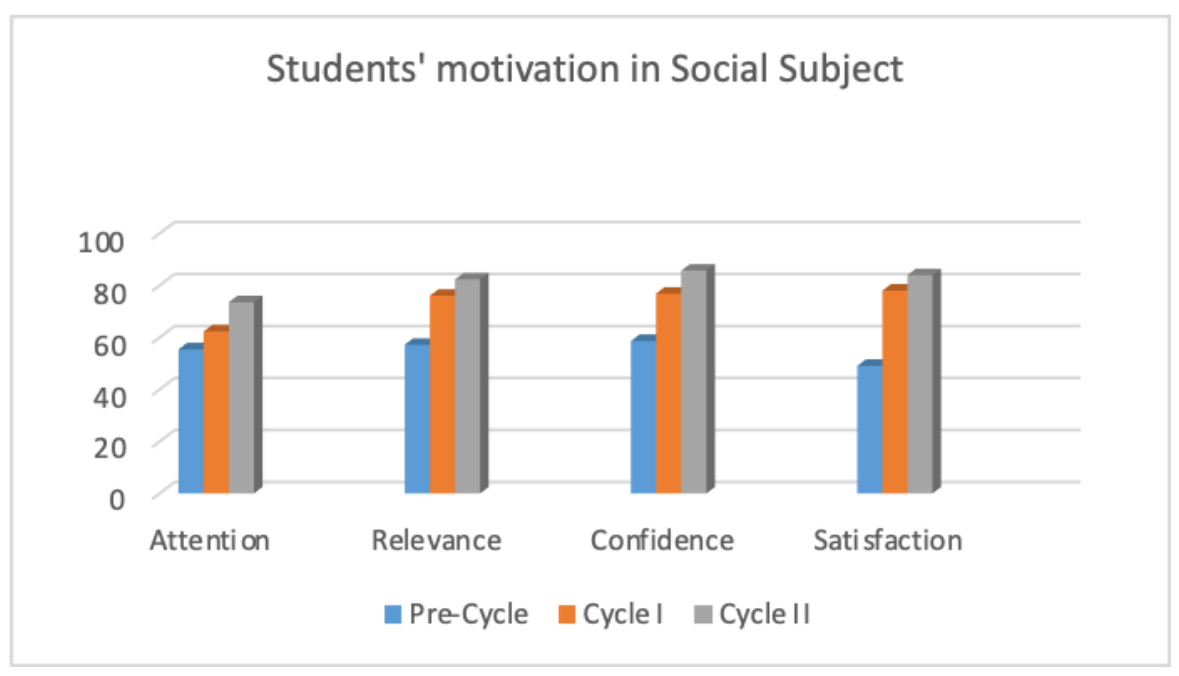

Figure 1. Questionnaire results on Students' motivation in Social Subject

\section{Discussion}

The research results that the social science learning activities carried out in the fifth-class of Elementary School, Bantul, Yogyakarta using an edutainment-based learning model with PowerPoint, in general, had been in accordance with the plan which was developed from the direct learning model. The learning process in this study was carried out in 5 phases, namely conveying objectives and preparing students; demonstrating knowledge; guiding training; checking students' understanding and providing feedback; providing training and concepts application. The five phases above were then packaged into 3 main learning activities, namely opening, core activities, and closing.

The results of interviews with several students, it shows that they are happy with learning using an edutainment-based learning model with the developed PowerPoint. The students admitted that they felt enthusiastic when participating in the learning activities. It showed a positive impact on the students' motivation during the social science learning. The majority of learners who were exposed to power-point presentations in the classroom, had positive attitudes towards the benefits of them to facilitate learning (Lari, 2014). The use of multimedia like video or PowerPoint is very effective because there are moving pictures, sounds, and attractive colors that make students curious and pay attention to the teacher (Sihotang, R. et al., 2021). The better student attention was also influenced by the increase of the students' self-confidence where it can be seen from the improvement in the percentage for aspects of the students' self-confidence before and after the study. Before the research, the students' motivation in social studies learning for the self-confidence aspect was $58.65 \%$ or in the medium category, after the action, it increased to 76.88 in the first cycle with the high category, and $85.71 \%$ for the second cycle, respectively. It supports the claim that students are capable to learn with good instruction given by the PowerPoint because the variety of design and animation could stimulate students' interest and learn well in the classroom (Guma et al., 2013). It urges instructors to integrate features of PowerPoint in ways that help students learn (Penciner, 2013).

The students' curiosity about the social science learning process was also getting better. The interview result indicated that the students were happy to learn with the developed PowerPoint. They were enthusiastic during the classroom learning process that reflected in their active learning participation. Power Point Game is powerful and beneficial media to give an effect toward the students' learning motivation and English achievement (Budasi et al., 2020). Similarly, the existence of technology in the classroom is beneficial for learning as a result of being a motivational tool for learner (Oktaviana, S., Santoso, B., \& Hiltrimartin, 2017). It can be concluded that the students felt enjoy and fun in the learning process and it increased their motivation in learning. Hence, the use of PowerPoint games gave a significant effect on students' learning motivation. Another finding proves that young learners in the experimental group achieved better than the control group seen from the mean score which was higher and there was a significant effect of PowerPoint game on young learners' English achievement since the significant value of one-way ANOVA was lower than 0.05 (Budasi et al., 2020). Power point and educational technology in general in the process of teaching Islamic studies plays a positive role both in the pedagogical and religious sense (Zedana et al., 2015). Moreover, the implementation of Islamic Religious Education strategy with the approach of PowerPoint media in the school was able to provide the motivation and spirit of learning students, the academic achievement rose significantly, the learning process is more interesting, more effective and efficient, easy to understand, easy to conditioned learners, 
adds to the confidence of the teacher, and is able to file more and more practical document files (Muthoifin \& Trihariyanto, 2020). However, several obstacles arose during the learning process in which the students needed a quite long time to understand the material and completed the given exercise since the material content became more complex and difficult so the materials should be adjusted with the students' ability and characteristics. Moreover, the tempo of material delivery by the teacher was considered too fast by the students. It made students hard to understand the material. In cycle II, it was overcome by accustoming the tempo in delivering the material and repeating the explanation to make sure the students grasp the information.

\section{CONCLUSION}

After applying social sciences learning using the developed PowerPoint, it can be concluded that there are significant improvements in case of students' attention and involvement in fifth-grade elementary schools. The finding of current study corresponds with some previous that proved that students' perception was positive on the implementation of innovative media (Power Point) toward their learning motivation. The teachers also response positively to the developed learning model for their teaching activities as an effort to enhance the students' learning motivation in social science learning and they consider it as a beneficial alternative learning model learning. Therefore, social science teachers should equip themselves with the ability to operate computers and create interactive learning media with PowerPoint. In addition, to make the learning process more efficient, teachers should prepare worksheets or modules for students to save time taking notes for students.

\section{REFERENCES}

Arikunto, S. (2016). Prosedur Penelitian Suatu Pendekatan Praktik (Revision). PT. Rineka Cipta.

Astini, N. K. S. (2020). Pemanfaatan Teknologi Informasi dalam Pembelajaran Tingkat Sekolah Dasar pada $\begin{array}{llll}\text { Masa Pandemi Covid-19. } & \text { Lampuhyang, }\end{array}$ https://doi.org/10.47730/jurnallampuhyang.v11i2.194.

Backfisch, I., Lachner, A., Hische, C., Loose, F., \& Scheiter, K. (2020). Professional Knowledge or Motivation? Investigating the Role of Teachers' Expertise on the Quality of Technology-Enhanced Lesson Plans. Learning and Instruction, 66, 101300. https://doi.org/10.1016/j.learninstruc.2019.101300.

Bahrami, Z. N., Izadpanah, S., \& Bijani, M. (2019). The Impact of Musical Mnemonic on Vocabulary Recalling of Iranian Young Learners. International Journal of Instruction, 12(1), 977-994. https://doi.org/10.29333/iji.2019.12163a.

Budasi, I. G., Ratminingsih, N. M., Agustini, K., \& Risadi, M. Y. (2020). PowerPoint Game, Motivation, Achievement: The Impact and Students' Perception. International Journal of Instruction, 13(4), 509-522. https://doi.org/10.29333/iji.2020.13432a.

Burn, A. (1999). Collaborative Action Research for English Language Teacher. Cambridge University Press.

Creswell, J. W. (2014). Research Design: Qualitative, Quantitative, and Mixed Methods Approaches. SAGE Publications.

Flick, U., Von Kardorff, E., \& Steinke, I. (2004). What is Qualitative Research? A Companion to Qualitative Research. Sage.

Genc Ilter, B. (2009). Effect of Technology on Motivation in EFL Classrooms. Turkish Online Journal of Distance Education, 10(4), 136-158. https://doi.org/10.17718/tojde.37730.

Guma, A., Faruque, A. H., \& Khushi, M. (2013). The Role of ICT to Make Teaching-Learning Effective in Higher Institutions of Learning in Uganda. International Journal of Innovative Research in Science, Engineering and Technology, 2(8), 4061-4073. http://137.63.168.4/handle/20.500.12260/23.

Hashim, S., Masek, A., Mahthir, B. N. S. M., Rashid, A. H. A., \& Nincarean, D. (2021). Association of Interest, Attitude and Learning Habit in Mathematics Learning towards Enhancing Students' Achievement. Indonesian Journal of Science \& Technology, 6(113-122). https://doi.org/10.17509/ijost.v6i1.

Hasnida, N., \& Ghazali, M. (2016). A Reliability and Validity of an Instrument to Evaluate the School-Based Assessment System: A Pilot Study. International Journal of Evaluation and Research in Education (IJERE), 5(6), 158-157.

Husain, C. (2014). The Use of ICT on Learning in Senior High School of Muhammadiyah Tarakan. Jurnal Kebijakan dan Pengembangan Pendidikan, 2(2), 184-192.

Juhana. (2014). Teaching English to Young Learners : Some Points to be Considered. Asian Journal of Education and E-Learning (ISSN:, 2(1), 43-46.

Lari, F. S. (2014). The Impact of Using PowerPoint Presentations on Students' Learning and Motivation in Secondary Schools. Procedia - Social and Behavioral Sciences, 98, 1672-1677. https://doi.org/10.1016/j.sbspro.2014.03.592. 
Lincoln, Y. S., Lynham, S. A., \& Guba, E. G. (2011). Paradigmatic Controversies, Contradictions, and Emerging Confluences, Revisited. In N.K. Denzin \& Y.S. Lincoln (eds), The Sage Handbook of Qualitative Research (4th ed.).

Madcoms. (2010). Presentasi Multimedia dengan MS-Powerpoint. Andi Offset.

Muthoifin, E. S., \& Trihariyanto, S. (2020). PowerPoint as a Strategy and Media Learning to Improve the Quality of Islamic Education. International Journal of Advanced Science and Technology, 29(7), 542-549.

Nagmoti, J. M. (2017). Departing from Powerpoint Default Mode: Applying Mayer's Multimedia Principles for Enhanced Learning of Parasitology. Indian Journal of Medical Microbiology, 35(2), 199-203. https://doi.org/10.4103/ijmm.IJMM_16_251

Oktaviana, S., Santoso, B., \& Hiltrimartin, C. (2017). Penggunaan Power Point Game pada Pembelajaran Lingkaran di Kelas VIII SMP Negeri 1 Tanjung Raya. Jurnal Pendidikan Matematika, 11(1), 29-42. https: //doi.org/10.22342/jpm.11.1.4131.29-42.

Ozaslan, E. N., \& Maden, Z. (2013). The Use of Powerpoint Presentations in the Department of Foreign Language Education at Middle East Technical University. Middle Eastern \& African Journal of Educational Research, 2, 38-45.

Penciner, R. (2013). Does PowerPoint Enhance Learning? Canadian Journal of Emergency Medicine, 15(2), 109-112. https://doi.org/10.2310/8000.2013.130756.

Puspitarini, Y. D., \& Hanif, M. (2019). Using Learning Media to Increase Learning Motivation in Elementary School. Anatolian Journal of Education, 4(2), 53-60. https://doi.org/10.29333/aje.2019.426a.

Rahardjanto, A., Husamah, \& Fauzi, A. (2019). Hybrid-PjBL: Learning Outcomes, Creative Thinking Skills, and Learning Motivation of Pre-Service Teacher. International Journal of Instruction, 12(2), 179192. https://doi.org/10.29333/iji.2019.12212a.

Ratminingsih, N. M. (2016). Efektivitas Media Audio Pembelajaran Bahasa Inggris Berbasis Lagu Kreasi di Kelas Lima Sekolah Dasar. JPI (Jurnal Pendidikan Indonesia), 5(1), 27. https: //doi.org/10.23887/jpi-undiksha.v5i1.8292.

Ratminingsih, N. M. (2018). Implementasi Board Games dan Pengaruhnya terhadap Hasil Belajar Bahasa Inggris. Jurnal Pendidikan Indonesia, 24(1), 19-28. https://doi.org/10.17977/um048v24i1p1928.

Rivai, Sudjana, N., \& Ahmad. (2003). Teknologi Pengajaran. Sinar Baru Algesindo.

Sihotang, R., A., Cendana, W., K., \& C., D. (2021). The Use of Video in Improving Students' Attention in Learning Process of Kindergarten Students. International Journal of Elementary Education, 4(4), 496-502. https://doi.org/10.23887/ijee.v4i4.28430.

Trisnani, N. (2020). Peningkatan Kemampuan Komunikasi Matematika Siswa SD Kelas V Melalui Tipe Pembelajaran Think Talk Write (TTW). Scholaria: Jurnal Pendidikan Dan Kebudayaan, 10(2), 92102. https://doi.org/10.24246/j.js.2020.v10.i2.p92-102.

Zedana, A. M., Yusoffa, M. Y. Z. B. M., \& Mohameda, R. Bin. (2015). An innovative Teaching Method in Islamic Studies: the Use of PowerPoint in University of Malaya as Case Study. Procedia - Social and Behavioral Sciences, 182, 543 - 549. https://doi.org/10.1016/j.sbspro.2015.04.776. 